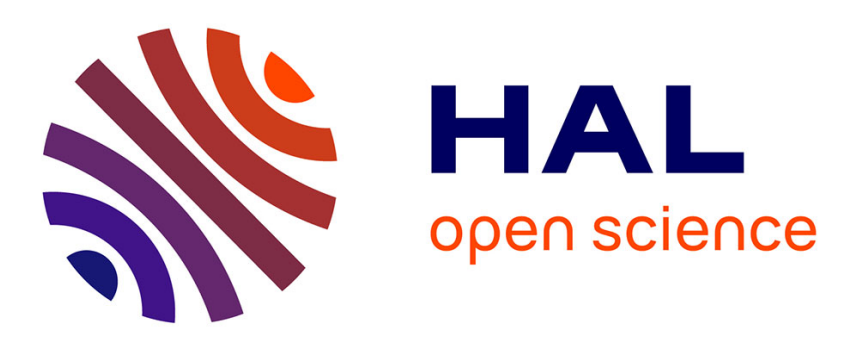

\title{
Understanding the link between aggregated industrial production and the carbon price
}

\author{
Julien Chevallier
}

\section{To cite this version:}

Julien Chevallier. Understanding the link between aggregated industrial production and the carbon price. The Economics of Green Energy and Efficiency, Springer, pp.1-22, 2013. halshs-00846340

\section{HAL Id: halshs-00846340 \\ https://shs.hal.science/halshs-00846340}

Submitted on 19 Jul 2013

HAL is a multi-disciplinary open access archive for the deposit and dissemination of scientific research documents, whether they are published or not. The documents may come from teaching and research institutions in France or abroad, or from public or private research centers.
L'archive ouverte pluridisciplinaire HAL, est destinée au dépôt et à la diffusion de documents scientifiques de niveau recherche, publiés ou non, émanant des établissements d'enseignement et de recherche français ou étrangers, des laboratoires publics ou privés. 


\title{
Understanding the link between aggregated industrial production and the carbon price
}

\author{
Julien Chevallier ${ }^{\S}$ \\ This version: July 2013 \\ First version: June 2012
}

\begin{abstract}
:
This chapter assesses the extent to which economic activity and the carbon price are linked. Carbon price drivers can be mainly related to energy and institutional variables. However, the influence of the macroeconomic environment shall not be undermined. Various approaches exist in the literature, which favor financial market variables over macroeconomic variables. Following a review of the state of the EU ETS, the main channel of transmission between the variation of macroeconomic activity and the carbon price is recalled, by using the aggregated industrial production as a proxy. An original empirical application unfolds, by studying the carbon-macroeconomy relationship in the threshold VAR model during 2005-2013. Further research is called upon in nonlinear econometrics.
\end{abstract}

Keywords : Carbon Price ; Economic Activity ; Industrial Production ; Nonlinear Time Series

JEL Codes : Q40 ; Q48 ; Q54

Citation: pls. Cite this document as:

"Chevallier, J. 2013. Understanding the link between aggregated industrial production and the carbon price. In The Economics of Green Energy and Efficiency, Eds. Galarraga, I., GonzalezEguino, M., and Ansuategi, A. Editions: Springer, forthcoming."

$\S$ IPAG Business School, IPAG Lab, 184 Boulevard Saint-Germain, 75006 Paris, France.

Tel: $+33 \quad(0) 1 \quad 49 \quad 40 \quad 73 \quad 86$. Fax: +33 (0)1 $49 \quad 40 \quad 72 \quad 55$. Email : julien.chevallier04@univ-paris8.fr Acknowledgments: For helpful comments on previous versions, I wish to thank Bruce Mizrach, Daniel Rittler, Neil R. Ericsson, Hans-Martin Krolzig, Emilie Alberola, Benoît Sévi, Anna Creti, Philipp Koenig, Fabien Roques, Benoît Leguet, Kenneth Roskelley, Alexander Kurov, Mikel Gonzalez, Ibon Galarraga, Alberto Ansuategi, Georg Zachmann, Paulina Beato, Jobst Heitzig, Jürgen Kurths, Philipp Ringler, Matthias Reeg, Antoine Mandel, Nicola Botta, Eric Smith, Doyne Farmer, Florian Landis, Robert Schmidt, Ulrike Konneke; and seminar participants at the $19^{\text {th }}$ Annual Symposium of the Society for Nonlinear Dynamics and Econometrics (Washington DC), the $65^{\text {th }}$ European Meeting of the Econometric Society (Oslo), the HEC Energy \& Finance Chair Research Conference on "The Behavior of Carbon Prices" (Paris), the $48^{\text {th }}$ Annual Meeting of the Eastern Finance Association (Boston), the BC3 Low Carbon Programme Workshop on "The Economics of Green Energy and Efficiency" (Bilbao), the PIK Workshop on "Modelling Carbon Prices - Interacting agent networks \& Strategies under risk" (Potsdam). 


\section{Introduction}

The EU Emissions Trading Scheme (EU ETS) is arguably the flagship of Europe's climate policy approach to achieve its 2020 emissions target (-20\%). As a cap-and-trade program, it represents a central economic tool to achieve a cost effective and smooth transition to a low carbon economy. However, while carbon markets have been the predominant policy response to address greenhouse gases mitigation in many countries, the carbon economy currently looks bleak. There are currently no binding global targets beyond 2012 (post-Kyoto). In December 2011, the Durban COP/MOP meeting has given a temporary lifeline to the CDM, but not on its longer term future (after 2015).

As a consequence, the uncertainty about the future of the markets, in combination with recurrent fears about "over-allocation" within the EU ETS as well as the impact of the recession on emissions themselves, have kept carbon prices at relatively low levels. Despite this absence of a binding international agreement, several new or emerging systems and regional initiatives are underway that result in the creation of new domestic markets (RGGI, California, Western Climate Initiative, Australia, China, South Korea, REDD+, etc.).

Against this institutional background, economic activity is perhaps the most obvious and least understood driver of $\mathrm{CO}_{2}$ price changes. Economic growth leads to increased energy demand and higher industrial production in general. Despite numerous contributions in the field of carbon price modeling (e.g. supply and demand fundamentals, expected future regulatory action, etc.), the last puzzle to be solved in relation to the price drivers of European Union Allowances (EUAs) is thus to determine the influence of economic activity, through changes in $\mathrm{CO}_{2}$ emissions levels.

This link between the carbon market and economic activity can be captured by the interaction between the price of $\mathrm{CO}_{2}$ and changes in the levels of industrial production. Indeed, it is widely acknowledged in macroeconomics that changes in the rate of utilization of industrial capacities provide an early warning of future changes in the levels of GDP. Therefore, industrial production can be considered as a good proxy for the evolution of the economic activity in the industrial sectors regulated by the EU ETS.

This relationship may be understood intuitively: as industrial production increases, associated $\mathrm{CO}_{2}$ emissions increase, and therefore more $\mathrm{CO}_{2}$ allowances are needed by operators to cover their emissions. This economic logic results in carbon price increases ceteris paribus. More work is needed on this topic, especially to understand the adjustment process of carbon prices to the macroeconomic environment, for instance by focusing on the underlying nonlinearities of the data. Since 2008, the deep recession arising from the financial crisis has spread to the sphere of commodities (including $\mathrm{CO}_{2}$ ), and it has very much depressed the carbon price signal. As of today's state-of-the-art literature, there lacks a comprehensive study on the adjustment of the price of carbon to the global economic recession that this chapter aims to fill.

The remainder of the chapter is organized as follows. Section 2 provides a background discussion on the current status of the EU ETS. Section 3 explains the main mechanism at stake concerning the link between the carbon price and the macroeconomy, along with the findings from previous literature. Section 4 develops the empirical analysis based on the class of threshold VAR models. Section 5 briefly concludes. 


\section{Current issues in the EU ETS}

As a brief reminder, the perimeter of the scheme covers approximately 11,000 installations in the EU27, i.e. it accounts for $45 \%$ of EU greenhouse gases.

In addition, the ETS is a liquid market, with millions of allowances traded each day on a number of exchanges, and over-the-counter. For instance, the average daily trading volume in 2011 was equal to 23 million EUAs (including futures), summing up to an amount of 6 billion annual trading volume. Until the end of June 2012, the accumulated total trading of futures since the creation of the scheme was equal to 20.4 billion allowances.

In this section, we first discuss the figures of the 2011-12 compliance data, and second some uncertainties pertaining to the future development of the European carbon market.

\subsection{A look at the 2011-2012 compliance data}

According to the compilation of preliminary data by Point Carbon ${ }^{1}$, the phase II of the EU ETS was oversupplied by 1.7 billion $\mathrm{CO}_{2}$ units, with almost half the surplus coming in 2012. Let us breakdown this information over the last two compliance years 2011-2012.

\subsubsection{Year 2011}

According to Carbon Market Data ${ }^{2}$, installations were long by $87 \mathrm{Mt}$ in 2011 . It implies that installations emitted in total $4.9 \%$ less $\mathrm{CO}_{2}$ than the number of allowances allocated - a total of 1,985 million allowances. Similarly, a $2.1 \%$ drop in $\mathrm{CO}_{2}$ emissions was recorded during the corresponding year.

In 2011, emissions from the combustion sector (which accounts for $70 \%$ of EU ETS emissions) showed a $2.2 \%$ decrease. Other industrial sectors have seen their $\mathrm{CO}_{2}$ emissions falling for ceramics $(-32.3 \%)$, cement $(-20.2 \%)$, or steel $(-14.1 \%)$ for instance.

Following the release of verified emissions reports ${ }^{3}$ for the year 2011, RWE, Vattenfall and E.ON were the three biggest $\mathrm{CO}_{2}$ emitters of the EU ETS by emitting respectively $141 \mathrm{MtCO}_{2}, 92 \mathrm{MtCO}_{2}$ and $86 \mathrm{MtCO}_{2}$. The Italian energy giant Enel is ranked at the fourth position, with $\mathrm{CO}_{2}$ emissions totaling $78 \mathrm{MtCO}_{2}$. Finally, EDF, the French group, was in 2011 the fifth biggest emitter with 67 $\mathrm{MtCO}_{2}$.

Additional data are available for the year 2011:

- The three companies with the highest surplus of freely allocated EUAs were two steel

1 See the news release "EU carbon market oversupplied by 1.7 bln: analysts" dated April 2, 2013 at www.pointcarbon.com.

Available at www.carbonmarketdata.com. Last accessed October 4, 2012.

3 These figures are calculated at group level, taking into account both minority and majority stakeholdings in other companies included in the EU emissions trading scheme. Figures do not include the EU allowances distributed for free to new entrants, as these data are not shown in the Community Independent Transaction Log (the EU carbon trading registry, also called CITL). A "new entrant" is defined in the EU directive establishing the carbon trading scheme as a new installation, or as an existing installation that has experienced a change of its activity "in the nature or functioning or extension of the installation". Data on the number of EU carbon allowances distributed to these new entrants are not made available publicly in the EU carbon registry. Only the emissions reports of these installations are published. 
makers and one cement manufacturer: ArcelorMittal (34 Mt), Corus (16 Mt) and Lafarge (11 $\mathrm{Mt})$. This ranking is unchanged compared to the previous year.

- The three companies having in 2011 the highest shortage of EU carbon allowances are all involved in the electricity generation business. ${ }^{4}$ These companies are RWE (shortage of 49 Mt), Vattenfall (27 Mt) and Drax Power (12 Mt).

- The three companies having surrendered the biggest number of Certified Emissions Reductions (CERs) to EU Member States are ArcelorMittal (25 million CERs), Lafarge (11 million CERs) and Enel (7.5 million CERs).

- The three companies having surrendered the biggest quantity of Emissions Reductions Units (ERUs) for 2011 compliance are ThyssenKrupp (8.2 million ERUs), ArcelorMittal (4 million ERUs) and Repsol (3.5 million ERUs).

\begin{tabular}{|c|c|c|c|c|}
\hline & Company & Sector & $\begin{array}{l}\mathrm{CO}_{2} \text { Emissions } \\
2011\left(\mathrm{MtCO}_{2}\right)\end{array}$ & $\begin{array}{l}\text { Free carbon } \\
\text { allowances } \\
2011 \\
\left(\mathrm{MtCO}_{2}\right)\end{array}$ \\
\hline \multicolumn{5}{|c|}{ UK } \\
\hline 1 & EDF & Power \& Heat & 22.4 & 16.0 \\
\hline 2 & $\begin{array}{l}\text { Scottish and } \\
\text { Southern } \\
\text { Energy }\end{array}$ & Power \& Heat & 22.1 & 15.3 \\
\hline 3 & Drax Power & Power \& Heat & 21.5 & 9.5 \\
\hline 4 & E.ON & Power \& Heat & 19.0 & 17.6 \\
\hline 5 & RWE & Power \& Heat & 15.7 & 17.0 \\
\hline \multicolumn{5}{|c|}{ Germany } \\
\hline 1 & RWE & Power \& Heat & 114.3 & 62.3 \\
\hline 2 & Vattenfall & Power \& Heat & 72.9 & 48.8 \\
\hline 3 & E.ON & Power \& Heat & 42.4 & 32.8 \\
\hline 4 & $\begin{array}{l}\text { Evonik } \\
\text { Industries }\end{array}$ & Chemicals & 20.4 & 20.2 \\
\hline 5 & ThyssenKrupp & Iron \& Steel & 17.6 & 25.6 \\
\hline \multicolumn{5}{|c|}{ France } \\
\hline 1 & ArcelorMittal & Iron \& Steel & 18.8 & 24.5 \\
\hline 2 & EDF & Power \& Heat & 15.7 & 19.2 \\
\hline 3 & Total & Oil \& Gas & 10.4 & 13.1 \\
\hline 4 & GDF SUEZ & Power \& Heat & 6.3 & 8.9 \\
\hline 5 & Lafarge & Cement \& Lime & 4.6 & 6.0 \\
\hline \multicolumn{5}{|c|}{ Italy } \\
\hline 1 & Enel & Power \& Heat & 36.8 & 32.2 \\
\hline 2 & Eni & Oil \& Gas & 24.0 & 25.5 \\
\hline 3 & Edison & Power \& Heat & 19.7 & 17.3 \\
\hline 4 & Riva Group & Iron \& Steel & 10.4 & 13.8 \\
\hline 5 & E.ON & Power \& Heat & 7.6 & 8.1 \\
\hline \multicolumn{5}{|c|}{ Spain } \\
\hline 1 & Endesa (Enel) & Power \& Heat & 34.5 & 23.4 \\
\hline 2 & Repsol & Oil \& Gas & 14.2 & 16.0 \\
\hline 3 & $\begin{array}{l}\text { Gas Natural } \\
\text { Fenosa }\end{array}$ & Power \& Heat & 14.2 & 11.9 \\
\hline 4 & $\begin{array}{l}\text { hc energía } \\
\text { (EDP) }\end{array}$ & Power \& Heat & 8.3 & 5.3 \\
\hline 5 & Iberdrola & Power \& Heat & 7.3 & 8.3 \\
\hline
\end{tabular}

Table 1: Company Rankings of Largest Emitters in 2011 by Country Source : Carbon Market Data

\footnotetext{
4 These three companies all have an energy mix with a high proportion of coal- or lignite-fired electricity generation.
} 
Table 1 displays the company rankings of the five biggest $\mathrm{CO}_{2}$ emitters per country (the United Kingdom, Germany, France, Italy and Spain), taking into account power plants and factories based on the respective national territory (i.e. this is not an EU-wide company ranking).

These figures are characteristic of a wider macroeconomic context of fall in demand (allowances and energy), mostly due to the economic downturn and mild temperatures during the reference compliance year.

Note that this diagnostic does not apply uniformly to all EU ETS sectors. For instance, an increase in $\mathrm{CO}_{2}$ emissions was recorded in the glass sector $(+3 \%)$.

\subsubsection{Year 2012}

In 2012, installations were long by $164 \mathrm{Mt}$ in 2012 (they emitted 164 million tons $\mathrm{CO}_{2}$ less than their number of freely received carbon allowances). ${ }^{5}$ This figure is derived from the verified emissions data for $95 \%$ (in volume) of the 11,300 installations included in the trading scheme. It shows that EU ETS installations emitted - in total - 8\% less $\mathrm{CO}_{2}$ than the number of allowances they received for free.

EU countries allocated to their installations a total of 2,034 million allowances. Verified emissions data submitted so far show that these installations emitted during the same period 1,786 $\mathrm{Mt}^{\mathrm{CO}_{2}}$. This represents an average decrease in $\mathrm{CO}_{2}$ emissions of $1.4 \%$ per installation in 2012 over 2011 (this figure takes into account only the installations that have submitted their emissions report).

This decrease in $\mathrm{CO}_{2}$ emissions was expected by most analysts, and may be due to the economic stagnation in Europe combined with the effect of energy efficiency and renewable energy policies, despite low coal and carbon prices.

RWE, Vattenfall and E.ON were the three biggest $\mathrm{CO}_{2}$ emitters of the EU emissions trading scheme during the year 2012. RWE, E.ON and Vattenfall emitted in 2012 respectively $157 \mathrm{MtCO}_{2}, 92$ $\mathrm{MtCO} 2$ and $90 \mathrm{MtCO} 2$. RWE had in 2012 a shortage of 45 million carbon allowances.

Additional data are available for the year 2012:

- The three companies with the highest surplus of EUAs were two steel makers and one cement manufacturer: ArcelorMittal (37 million EUAs surplus), Tata Steel (17 million EUAs surplus) and Lafarge (12 million EUAs surplus).

- The three companies having in 2012 the highest shortage of EU carbon allowances are all involved in the electricity generation business. These companies are RWE (shortage of 45 Mt), Vattenfall (28 Mt) and Enel (17 Mt).

- The three companies having surrendered the biggest number of CERs to EU Member States are E.ON (27 million CERs), Enel (16.5 million CERs) and GDF-Suez (8.5 million CERs).

- The three companies having surrendered the biggest quantity of ERUs for 2012 compliance are RWE (15 million ERUs), CEZ (12.5 million ERUs) and E.ON (11 million ERUs).

In 2012, only two countries allocated to their installations - in aggregate - less free allowances than they emitted: Germany (29 Mt) and the United Kingdom $(2.5 \mathrm{Mt})$. All the other countries allocated to their installations more allowances than the amount of carbon emitted in 2012. Romania (-26

\footnotetext{
5 These figures include the 27 EU countries except Bulgaria and Cyprus.
} 
Mt), France (-25 Mt), the Czech Republic (-17 Mt), Spain (-17 Mt), and Poland (-16 Mt) are topping the list of countries with a surplus in EU carbon allowances.

In terms of emissions evolution between 2012 and 2011, nine countries saw an increase of their $\mathrm{CO}_{2}$ emissions. Malta $(+7.5 \%)$, Ireland $(+7 \%)$ and the UK $(+4.7 \%)$ experienced the highest increases in $\mathrm{CO}_{2}$ emissions. Countries that witnessed a decrease in their $\mathrm{CO}_{2}$ emissions level in 2012 are topped by Northern European countries: Finland (-15\%), Denmark (-15\%), Estonia (-8.5\%) and Sweden ($8.3 \%)$. Finland and Denmark had made exactly the same performance last year, i.e. these two countries reduced their $\mathrm{CO}_{2}$ emissions by nearly 30\% from 2010 to 2012 .

Figure 1: Emissions-To-Cap Ratio in 2012 by Country

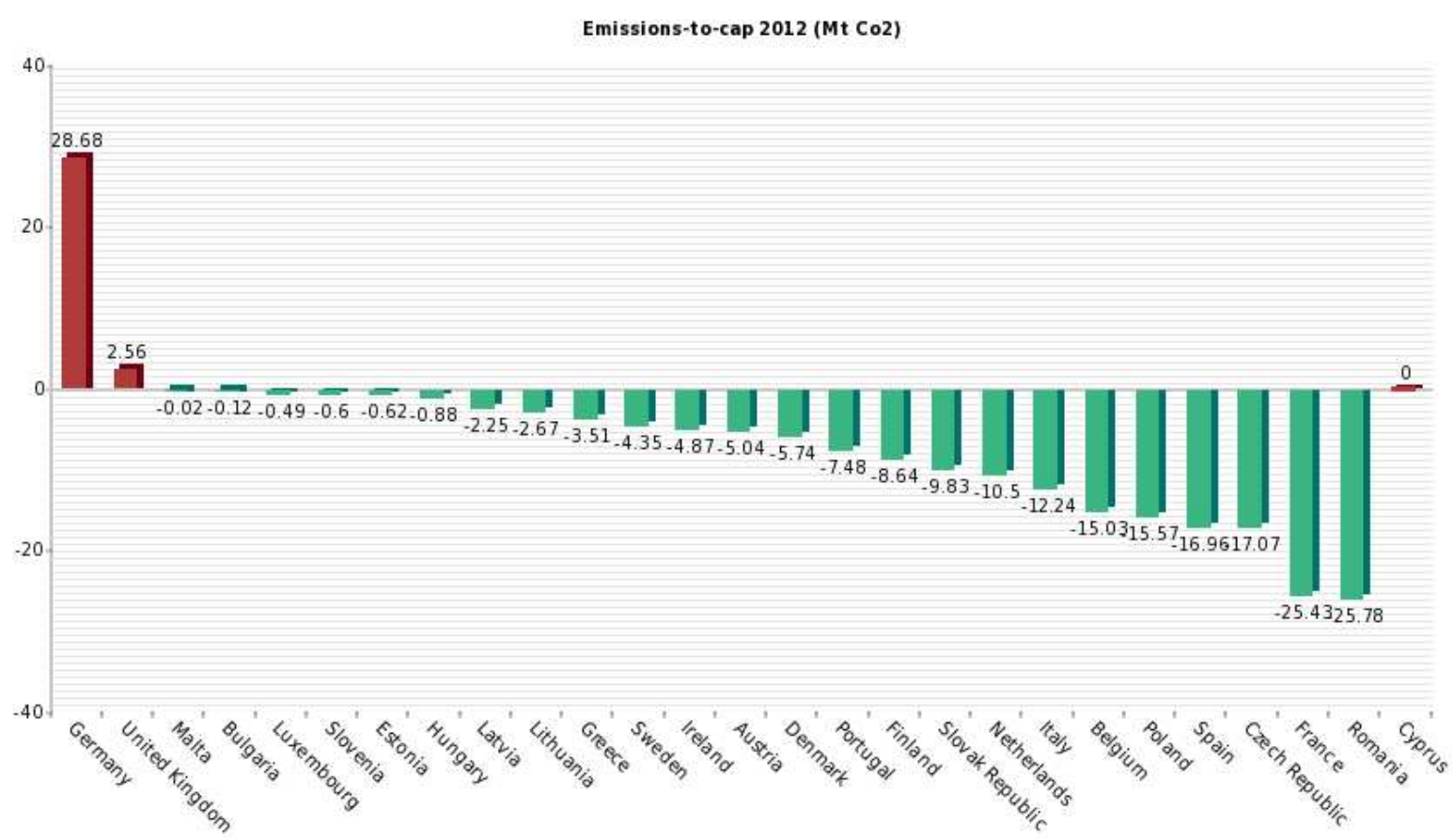

Source : Carbon Market Data

Figure 1 shows the emissions-to-cap ratio in 2012 by country. This graph reveals that only two countries (Germany and the UK) were short of allowances during the compliance year 2012, while other countries were in a more favorable position, with larger amounts of allocated allowances than verified emissions for that vintage.

Following this up-to-date presentation of the state of the EU ETS in terms of emissions data, we address in the next section various regulatory issues regarding the evolution of the scheme.

\subsection{Rising uncertainties}

First, uncertainties are especially acute on the supply side of the market. The cumulative surplus transferable into phase III has reached $1.5 \mathrm{Gt} \mathrm{CO}_{2}$-equivalent (or $80 \%$ of annual emissions of the EU ETS installations). The current low price of EUAs (in the range of 6-7 Euro/ton of $\mathrm{CO}_{2}$ ) logically responds to this imbalance between the supply and demand of allowances. 
Given the current economic outlook, which options are available to the regulator to attempt to fix the situation? One solution could lie in the permanent cancellation of the quota set-aside, which would have the direct effect to restore the balance between supply and demand, and hence increase the price of carbon.

In December 2011, the EP ENVI has voted on the perception that a 1.4 billion permanent set-aside was decided. Further on this topic, the European Commission published in November 2012 its ETS market review, as part of plans to tackle a huge surplus of carbon permits that has depressed the market $^{6}$.

Besides, the proposal to delay the $\mathrm{CO}_{2}$ allowance auctions (backloading) was rejected by the European Parliament on April 16, 2013 and referred to the Parliament's ENVI Commission. A new plenary session vote has been scheduled for early July 2013. This state of affairs has led some critics to consider the EU ETS as a "zombie" public policy (Tendances Carbone, 2013) characterized by a four euro price path.

Second, the scope of the EU ETS has recently been extended. Since January 1, 2012 the aviation sector has been included in the EU ETS - thereby tackling the $\mathrm{CO}_{2}$ emissions coming from transport. However, lawsuits have been coming from some EU as well as non-EU Member-States to protest against this scheme. Against the over-allocation background for other (non-aviation) EU ETS sectors, we may wonder whether this extension to aviation was such as good idea, and whether the timing for such a bold regulatory move was appropriate.

The legal challenge to the validity of the EU ETS, as applied to aviation and which was instigated by the Air Transport Association of America, supported by the International Air Transport Association (IATA) and the National Airlines Council of Canada (NACC), finally concluded with the judgment of the European Court of Justice Grand Chamber published on December 21, 2011. Not unexpectedly, the ECJ confirmed the validity of the EU ETS ${ }^{7}$. During the lawsuit, complex questions arised as to the potentially extra-territorial nature of the ETS as applied to airlines, whether it infringes sovereignty of airspace of non-EU countries, and whether the EU ETS involves an unlawful charge or a tax on fuel (HFW, 2012).

Although the aviation component of the EU ETS has survived, the ECJ case by no means brings to an end the legal and political disputes on this issue. Airlines continue actively to consider their options for further legal action within the EU; a dispute resolution process under the aegis of ICAO (the International Civil Aviation Organization) continues to be a likely forum for further challenge; the US is pursuing its own legislation, which would prohibit US carriers from complying with the EU ETS, and certain international carriers and industry associations are threatening straightforward non-compliance.

As a consequence, Point Carbon $^{8}$ indicates that political pressure may force the EU to show flexibility when it comes to resolving the dispute over including airlines in its carbon market - by either being lenient when it comes to policing the scheme or generously interpreting conditions that allow it to repeal the law.

Last but not least, as mentioned in the Introduction, the status of the CDM and further EU ETS linkage are undermined by the absence of post-Kyoto agreements (after December 2012). Taken together, all these facts contribute to cast a veil of uncertainty on the future development of world and regional carbon markets.

6 See the Point Carbon news article at http://www.pointcarbon.com/news/1.1999756. Last accessed October 4, 2012. Air Transport Association of America e.a., v Secretary of State for Energy and Climate Change, Case C-366/10.

8 Available at http://www.pointcarbon.com/news/1.2004752. Last accessed on October 4, 2012. 


\section{The link between the $\mathrm{CO}_{2}$ price and industrial production}

In this section, we recall first the economic mechanism by which $\mathrm{CO}_{2}$ emissions, industrial production and carbon prices are theoretically connected. Then, we provide an overview of the current literature on this topic.

\subsection{Mechanism}

What is the impact of economic activity on the growth rate of carbon prices from an empirical point of view? Absent energy efficiency improvements (at least in the short-term), the link between growth and carbon pricing unfolds as follows:

1. Economic activity fosters high demand for industrial production goods.

2. In turn, companies falling under the regulation of the EU ETS need to produce more, and emit more $\mathrm{CO}_{2}$ emissions in order to meet consumers' demand.

3. This yields to a greater demand for $\mathrm{CO}_{2}$ allowances to cover industrial emissions, and ultimately to carbon price increases.

Of course, it would be better to work directly with $\mathrm{CO}_{2}$ emissions at the installation level, but there is a high degree of complexity in accessing this data, and making it available to the econometrician. Hence, we choose to proceed with the industrial production index as a good proxy of economic activity in this chapter.

\subsection{Previous studies}

Among early studies, we may refer to the theoretical literature reviews by Springer (2003) and Christiansen et al. (2005), who identified the following drivers of $\mathrm{CO}_{2}$ allowance prices:

- Policy and regulatory issues of the EU ETS : these include National Allocation Plans (NAPs), auctioning share of allowances, banking and borrowing allowances possibilities, new entrants reserve, new covered sectors, etc.;

- Emissions levels : among the factors impacting $\mathrm{CO}_{2}$ emissions, we may distinguish between

1. Economic activity: industrial production by covered installation, electricity power demand by others sectors;

2. Energy prices: Brent, natural gas, coal;

3. Weather conditions: temperature and rainfalls.

Therefore, we observe that economic activity was directly thought as being one of the fundamental drivers of carbon prices in the literature that was published before the creation of the EU ETS.

However, the first empirical studies neglected that impact, and focused more heavily on the role played by other energy markets in shaping the price of carbon. We may cite in this strand of literature the papers by:

- Kanen (2006): the author finds that coal, natural gas and oil prices impacted carbon futures of maturity December 2006 ;

- Mansanet et al. (2007): they document that Brent ICE and natural gas NBP impacted carbon spot prices from January to November 2005 ;

- Bunn and Fezzi (2009): in a cointegrated vector error-correction model, the authors establish that natural gas and carbon prices jointly influence the equilibrium of electricity. 
Interestingly, one has to wait until late 2008-2009 to find published research papers including explicitly industrial production (as a proxy of economic activity) as one additional factor potentially impacting the price path of carbon. These first stylized analyses are due to Alberola et al. (2008, 2009), who provide the first rigorous econometric exercises aimed at disentangling the potential impacts ranging from production to environmental conditions on carbon prices. By instrumenting industrial production indices at the EU ETS sector-level, the authors show empirically that fluctuations in the level of economic activity are a key determinant of the level of carbon price returns in the combustion, paper and iron sectors (which account for nearly eighty percent of allowances allocated), and in four countries (Germany, Spain, Poland, UK). Although, one limit of these studies is that they considered exclusively linear econometric models, while the underlying relationships at stake could essentially be understood as being nonlinear (for instance, the effects of temperatures on carbon prices can only be detected above or below a given threshold). This limitation has now been tackled by some of the papers mentioned below.

In a different setting, Hintermann (2010) derives a structural model of the allowance price under the assumption of efficient markets during phase I of the EU ETS. In his model, changes in the optimal amount of abatement are a function of several variables including temperatures, precipitations, fuel prices, but also a proxy for overall economic performance in the EU: the FTSE Eurotop 100. This latter variable is a tradable index representing the 100 most highly capitalized blue chip companies in Europe, and therefore belongs to the category of financial markets indicators.

It is worth noting here that the econometrician has broadly two types of choices when deciding on the proxy for economic activity. Either he can specify a variable which is by definition macroeconomic, in the sense that it corresponds to the reality of physical exchanges in the economy (such as industrial production processes). Or he can opt for a more financial approach, whereby liquid and efficient markets are supposed to reflect instantly the public information readily available concerning the state of the economy (e.g. news releases on macroeconomic aggregates).

Depending on this choice, different types of conclusion will of course be drawn from the study. For a genuine macroeconomic approach, industrial production-type indices will certainly be the preferred choice of the econometrician. As another consequence, the following literature can be further divided into two sub-categories:

1. The "financial markets" approach : these studies include Hintermann (2010), but also Creti et al. (2012) who use the Dow Jones Euro Stoxx 50 as the equity price index in their estimation strategy of carbon price drivers (including as well Brent and the switch price). Aatola et al. (2013) use the FTSE 350 as their economic activity proxy, among other energy market fundamentals.

Note that the investigation of macroeconomic risk factors ${ }^{9}$ specific to the EU ETS by Chevallier (2009), as well as the impulse response function analysis in the Factor-Augmented Vector AutoRegressive (FAVAR) framework conducted by Chevallier (2011a) could also fall in this category.

9 i.e. dividend yields, junk bond yields, T-bill rates and market portfolio excess returns in the Fama-French literature. 
2. The "macroeconomic" approach: in this category, we will find the early work by Alberola et al. (2008, 2009), as well as a series of new studies.

First, Chevallier (2011b) provides several nonlinearity tests for the univariate time series of industrial production and carbon prices, which can satisfactorily be fitted with Self-Exciting Threshold AutoRegressive (SETAR) models. In addition, a multivariate econometric strategy featuring industrial production as the logistic transition function in a Smooth Transition AutoRegressive (STAR) model including both variables brings fruitful results. On the one hand, contemporaneous changes in the industrial production index impact negatively carbon price changes (i.e. the decrease in industrial production precedes the decrease in carbon prices). On the other hand, changes in the industrial production index lagged one period impact positively carbon price changes (i.e. the uptake in economic activity encourages the carbon price to go up).

Second, Chevallier (2011c) uses again the EU 27 industrial production index computed by Eurostat as a proxy of economic activity in the perimeter of EU ETS sectors. This choice is assessed based on a preliminary forecasting exercise including various candidates (monetary, industrial and financial variables): it could be shown that the industrial production index minimizes all criteria. Then, the originality of the article lies in the two-regime threshold cointegration exercise between EU industrial production and the carbon price. The threshold Vector Error-Correction Model (VECM) estimates reveal that the EU industrial production index impacts positively the EUA futures price: the carbon-macroeconomy relationship goes from the EU industrial production index (lagged one period) to the carbon futures price. On the contrary, the EUA futures price has no statistically significant effect on the EU industrial production index. In short, the industrial production index governs most of the adjustment from the short-run to the long-run equilibrium of the model. Should any short-term deviations occur, the industrial production index acts as a feedback force to restore the long-run equilibrium relationship. Hence, it can be concluded that industrial production leads the nonlinear mean-reverting behavior of the carbon price, but not vice versa.

Third, Chevallier (2011d) confirms that the presence of nonlinearities may contribute to explain why early regression studies did not capture well the carbon-macroeconomy relationship. In a tworegime Markov-switching model between industrial production and carbon prices, the author shows that industrial production has two types of effects on the carbon price: positive during the expansion regime, and negative during the recession regime. Macroeconomic activity is likely to affect carbon prices with a lag, due to the specific institutional constraints of this environmental market. Besides, the Markov regime-switching model captures most of the shocks identified on the carbon market (January-April 2005, April-June 2006, October 2008, and April 2009-present). In line with previous studies, no statistically significant impact going from the carbon price to industrial production could be detected (i.e. there is no "bounce back" effect). The results are robust to the introduction of energy dynamics (e.g. Brent, gas, coal).

While there seems to remain considerable uncertainties regarding the evolution of this carbonmacroeconomy relationship in phase III of the EU ETS with the shift to auctioning and the need to meet the EC 20/20/20 targets, the bottom line of this work can be summarized as follows. The carbon-macroeconomy relationship seems adequately captured by two-regime threshold errorcorrection and two-regime Markov-switching VAR models compared to linear models as main competitors. 
Finally, “mixed equity/industrial production" econometric strategies can also be found:

- Bredin and Muckley (2011) have used the industrial production index computed by Eurostat to capture the influence of economic activity in their equilibrium model of phase II carbon prices (including as well energy prices, equity prices and temperatures deviations). The financial markets indicator used is the Eurex Dow Jones Euro Stoxx futures contract. According to the authors, the motivation for including this variable is that it offers an up-todate indicator of expectations on both financial and economic conditions at the required daily frequency. Further, given the financial nature of the underlying asset, they consider including such a proxy informative. We can certainly agree upon that statement concerning the benefits of a mixed financial/macro approach.

- Mansanet-Bataller et al. (2011) have used the industrial production index calculated by Tendances Carbone, in conjunction with financial indicators such as the EU Economic Sentiment Index, the slope of the Euro area yield curve, the Reuters momentum variable concerning the EUA market, and the CBOE VIX volatility indicator. During phase II of the EU ETS, statistical significance could only be found for the EUA momentum variable.

Table 2 provides a useful summary of the categories of indicators used in previous studies as proxy for economic activity:

\begin{tabular}{|c|c|c|c|}
\hline \multirow[t]{2}{*}{ Reference } & \multirow[t]{2}{*}{ Period } & \multicolumn{2}{|c|}{ Economic Activity Proxy } \\
\hline & & Financial Approach & Macroeconomic Approach \\
\hline Aatola et al. (2013) & $\begin{array}{l}\text { January } 2005- \\
\text { December } 2010\end{array}$ & FTSE 350 & \\
\hline Alberola et al. (2008) & $\begin{array}{l}\text { July } 2005- \\
\text { April } 2007\end{array}$ & & $\begin{array}{c}\text { Tendances Carbones EU ETS } \\
\text { sectors industrial production }\end{array}$ \\
\hline Alberola et al. (2009) & $\begin{array}{l}\text { July } 2005- \\
\text { April } 2007\end{array}$ & & $\begin{array}{c}\text { Tendances Carbones EU ETS } \\
\text { sectors industrial production }\end{array}$ \\
\hline Chevallier (2009) & $\begin{array}{l}\text { April } 2005- \\
\text { October } 2008\end{array}$ & Euronext 100 & \\
\hline Hintermann (2010) & $\begin{array}{l}\text { January } 2005- \\
\text { June } 2007\end{array}$ & FTSE Eurotop 100 & \\
\hline $\begin{array}{l}\text { Bredin and Muckley } \\
\text { (2011) }\end{array}$ & $\begin{array}{l}\text { July } 2005- \\
\text { December } 2009\end{array}$ & Eurex Dow Jones Euro Stoxx & $\begin{array}{c}\text { Eurostat EU } 27 \text { industrial } \\
\text { production index }\end{array}$ \\
\hline Chevallier (2011a) & $\begin{array}{l}\text { April } 2008- \\
\text { January } 2010\end{array}$ & $\begin{array}{c}\text { Broad dataset of financial } \\
\text { times series }\end{array}$ & $\begin{array}{c}\text { Broad dataset of } \\
\text { macroeconomic time series }\end{array}$ \\
\hline Chevallier (2011b) & $\begin{array}{l}\text { January } 2005- \\
\text { July } 2010\end{array}$ & & $\begin{array}{l}\text { EU } 27 \text { Eurostat industrial } \\
\text { production index }\end{array}$ \\
\hline Chevallier (2011c) & $\begin{array}{l}\text { January } 2005- \\
\text { July } 2010\end{array}$ & & $\begin{array}{l}\text { EU } 27 \text { Eurostat industrial } \\
\text { production index }\end{array}$ \\
\hline Chevallier (2011d) & $\begin{array}{l}\text { January } 2005- \\
\text { July } 2010\end{array}$ & & $\begin{array}{l}\text { EU } 27 \text { Eurostat industrial } \\
\text { production index }\end{array}$ \\
\hline Creti et al. (2012) & $\begin{array}{l}\text { June } 2005 \text { - } \\
\text { December } 2010\end{array}$ & Dow Jones Euro Stoxx 50 & \\
\hline $\begin{array}{l}\text { Mansanet-Bataller et } \\
\text { al. (2011) }\end{array}$ & $\begin{array}{l}\text { March } 2007- \\
\text { March } 2009\end{array}$ & $\begin{array}{c}\text { EU Economic Sentiment } \\
\text { Index, Euro area yield curve, } \\
\text { Reuters EUA momentum, } \\
\text { CBOE VIX }\end{array}$ & $\begin{array}{l}\text { Tendances Carbone industrial } \\
\text { production index }\end{array}$ \\
\hline
\end{tabular}

Table 2: Summary of previous studies indicators of economic activity for carbon markets 


\section{Empirical analysis}

In our empirical analysis, we wish to develop a Threshold VAR model (TVAR) applied to the carbon-macroeconomy relationship. The focus here is to study the inter-relationships between the EU 27 industrial production index and the price of $\mathrm{CO}_{2}$ in a nonlinear framework.

The necessity to adopt such a methodological viewpoint compared to early studies - which were essentially based on linear regressions - has been further documented by Chevallier (2011e). In his review of the main results of the $\mathrm{CO}_{2}$ allowances price drivers, the author shows indeed that the results that were previously established can further vary depending upon the specification of higher or lower regimes in the time series data.

In what follows, we aim at taking the current literature on the carbon-macroeconomy relationship one step further by analyzing this link in the TVAR framework. This econometric strategy will allow us to decompose the joint variation of carbon prices and industrial production in two (high and low) regimes.

As such, it provides a useful and updated extension of the studies by Chevallier (2011b, SETAR and STAR models), Chevallier (2011c, two-regime Threshold cointegration), and Chevallier (2011d, two-regime Markov-switching VAR model).

\subsection{Data}

Let us first present the data used in this study. The dataset contains $\mathrm{CO}_{2}$ futures prices and the EU 27 Industrial production index, which were obtained from the European Climate Exchange (ECX), Thomson Financial Datastream, and Eurostat. The data sample goes from the opening of ECX on April 22, 2005 to January 25, 2013 (i.e. a sample of 2,008 daily observations).

The carbon price is the ECX EUA Futures price series in EUR/ton of $\mathrm{CO}_{2}$, rolled-over using front months contracts. In addition, concerning the macroeconomic variable of interest, we follow thoroughly the approach by Chevallier (2011c), who selected the EU 27 Industrial Production Index by Eurostat as the variable of interest to be used as a proxy for the influence of economic activity (to cope with the limitation of being unable to observe actual $\mathrm{CO}_{2}$ emissions at the plant level) ${ }^{10}$.

Both series are pictured in Figure 2. Concerning the EU industrial production (on the right Y-axis), we may distinguish three distinct phases during our study period. First, the period going from January 2005 to May 2008 may be viewed as a phase of economic growth. Second, we notice after May 2008 an abrupt decline in the industrial production, characterizing the entry of EU economies into the recession. These events follow with some delay the developments of the US economy, following the first interest rate cut by the Federal Reserve in July 2007. This event is mostly viewed as the start of the economic downturn, as the first signs of financial distress in the housing sector met the headlines. Third, from April 2009 until July 2010, we may observe a timid uptake in the industrial production. Therefore, our study period contains an interesting mix of economic growth, recession and recovery that we aim at analyzing jointly with the behavior of EUA Futures prices (on the left Y-axis). The latter time series seems to follow the same pattern, with the presence of shocks during 2005-2007 originating from institutional features of the EU ETS (see Ellerman et al. (2010) for an exhaustive coverage of this topic).

10 The EU 27 industrial production index has a base 100 in 2000, and is seasonally adjusted. The index is converted from monthly to daily frequency by using the Matlab function by L. Shure, which performs linear interpolation so that the mean square error between the original data and their ideal values is minimized. 
Figure 2: ECX Futures Price and EU Industrial Production Index

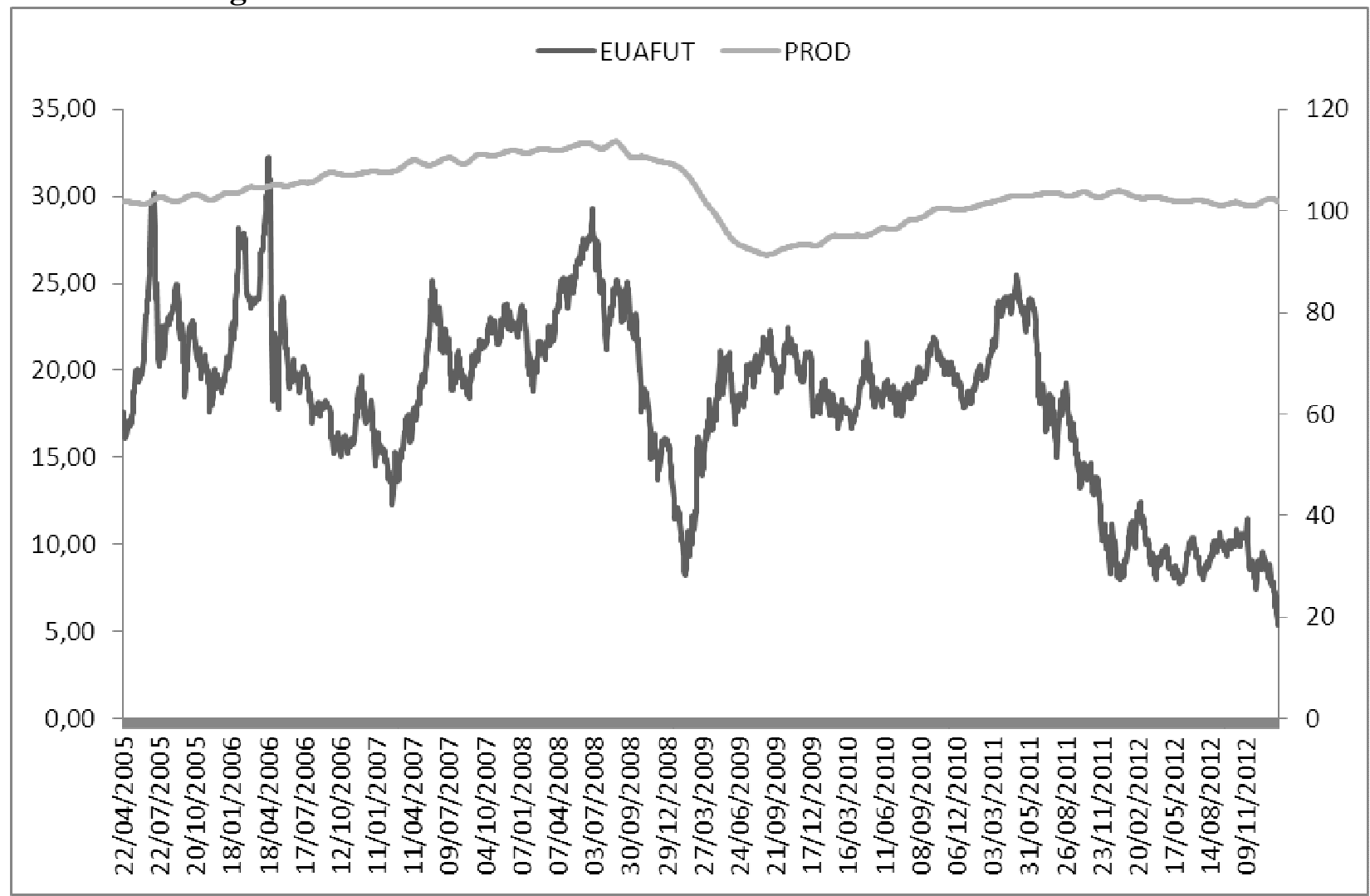

Source : European Climate Exchange, Thomson Financial Datastream, Eurostat

Descriptive statistics are presented in Table 3. They provide useful information on the distributional characteristics of the time series considered, and more especially concerning their non-Gaussianity. The price series are not stationary when taken in raw form, and stationary when transformed to logreturns (i.e. I(1)). Usual unit root tests (ADF, PP, KPSS) are not reproduced here to conserve space.

\begin{tabular}{lcc}
\hline & D(EUAFUT) & D(PRODIND) \\
\hline Mean & -0.000573 & $-8.58 \mathrm{E}-07$ \\
Maximum & 0.269001 & 0.000980 \\
Minimum & -0.288246 & -0.001910 \\
Std. Dev. & 0.030103 & 0.000515 \\
Skewness & -0.191137 & -1.169207 \\
Kurtosis & 13.66459 & 5.358974 \\
JB & 9527.929 & 923.0890 \\
Prob(JB) & 0.000000 & 0.000000 \\
Obs. & 2008 & 2008
\end{tabular}

Table 3: Summary Statistics for $\mathrm{CO}_{2}$ and Macroeconomic Variables

Note : EUAFUT stands for the ECX EUA Futures price, and PRODIND for the EU 27 Industrial Production Index from Eurostat. The operator $\mathrm{D}($.) refers to the log-return transformation of the time series. Std. Dev. Stands for Standard Deviation, JB for the Jarque Bera Test Statistic, Prob(JB) for the critical value of the Jarque Bera Test Statistic, and Obs. for the number of observations in daily frequency. 


\subsection{TVAR model}

Next, we present formally the TVAR model used. We build here on Balke (2000)'s notations:

$$
X_{t}=A^{0}(L) X_{t-1}+\left[A^{1}(L) X_{t-1}\right] I\left(c_{t-d}>r\right)+\varepsilon_{t}
$$

where $X_{t}$ denotes a vector a time series, $A^{0}(L)$ and $A^{l}(L)$ are lag polynomials, and $\varepsilon_{t}$ is the error term. $c_{t-d}$ is the threshold variable that determines which regime the system is in, $r$ is the threshold critical value, $\mathrm{I}\left(c_{t-d}>\mathrm{r}\right)$ is an indicator function that equals 1 when $c_{t-d}>r$, and zero otherwise. The threshold value $r$ is not known a priori, and must be estimated (see Hansen (1996)).

Before estimating the TVAR model, we need to implement a nonlinearity test in order to test formally whether the threshold-type behavior is rejected, or not. The test is the multivariate extension by Lo and Zivot (2001) of Hansen (1999)'s linearity test against various thresholds. As in the univariate case, the first threshold parameter is estimated by Conditional Least Squares (CLS) upon a grid of potential values for the threshold and the delays. Then, for the second threshold, a conditional search with one iteration is performed. Instead of a $F$-test comparing the Sum of Squared Residuals (SSR) for the univariate case, a Likelihood Ratio (LR) test comparing the covariance matrix of each model is computed:

$$
L R_{i j}=T\left(\ln \left(\operatorname{det} \hat{\Sigma}_{i}\right)-\left(\ln \left(\operatorname{det} \hat{\Sigma}_{j}\right)\right)\right.
$$

with $\hat{\Sigma}_{i}$ the estimated covariance matrix of the model with $i$-regimes (and $i$-thresholds), det the notation for the determinant of the matrix, and $T$ the number of observations. Three tests are presented:

1. Test 1vs2: Linear VAR versus 1-threshold TVAR;

2. Test 1vs3: Linear VAR versus 2-threshold TVAR;

3. Test 2vs3: 1-threshold TVAR versus 2-threshold TVAR.

The goal is to determine first whether a purely linear model is rejected (in favor of one or two thresholds). In the second step, once the presence of the threshold(s) has been confirmed, we aim at identifying whether a model with one or two thresholds is preferable (see Teräsvirta et al. (2011) for more details).

The model hyper-parameters (i.e. the possible thresholds and delays value) are determined by running an automatic search upon a grid of potential values ${ }^{11}$ (for more details, see Lo and Zivot (2001)). For a fixed threshold variable, the model is linear, so that the estimation of the two higherand lower-regimes can be done directly by CLS. The standard errors coefficients provided for this model are taken from the linear regression theory, and are to be considered asymptotical (Tong (1990), Franses and van Dijk (2003)).

\subsection{Results}

Estimation results are presented for a TVAR model containing the $\mathrm{CO}_{2}$ futures price and the EU industrial production index. The goal of this procedure is to assess the sensitivity of carbon prices relative to macroeconomic activity in the EU, as proxied by the influence of industrial production.

\footnotetext{
${ }^{11}$ An exhaustive search is conducted over all the possible combinations of values of the specified hyper-parameters. These results are not shown here to conserve space, and may be obtained upon request to the author.
} 


\begin{tabular}{|c|c|c|c|}
\hline \multicolumn{2}{|l|}{ Diagnostic Tests } & Stat. & $p$-value \\
\hline \multicolumn{2}{|c|}{ LR Test of Linearity (1vs2) } & 39.2378 & 0.0000 \\
\hline \multicolumn{2}{|c|}{ LR Test of Linearity (1vs3) } & 77.3049 & 0.0000 \\
\hline \multicolumn{2}{|c|}{$\begin{array}{l}\text { LR Test of TVAR(1) against } \\
\text { TVAR(2) }(2 v s 3)\end{array}$} & 38.0671 & 0.0000 \\
\hline \multicolumn{2}{|c|}{ Best Unique Threshold $($ Delay = 1) } & 0.0072 & \\
\hline \multicolumn{2}{|c|}{ Second Step Threshold (Delay = 2) } & 0.0302 & \\
\hline Lower Regime & D(EUAFUT) & \multicolumn{2}{|c|}{ D(PRODIND) } \\
\hline Constant & $\begin{array}{c}0.0346 * * * \\
(0.0007)\end{array}$ & \multicolumn{2}{|c|}{$(0.0006)$} \\
\hline D(EUAFUT)-1 & $\begin{array}{c}-7.4624 \mathrm{e}-06 * * * \\
(4.1612 \mathrm{e}-07)\end{array}$ & $5.4364 \mathrm{e}-05$ & $\begin{array}{l}4 e-05 \\
5 e-01)\end{array}$ \\
\hline D(PRODIND)-1 & $\begin{array}{c}-2.5196 \mathrm{e}-02 * * * \\
(7.3649 \mathrm{e}-06)\end{array}$ & $(-0.0004)$ & $\begin{array}{l}21 * * * \\
004)\end{array}$ \\
\hline D(EUAFUT)-2 & $\begin{array}{c}1.6839 \mathrm{e}-02 * * * \\
(2.4155 \mathrm{e}-05)\end{array}$ & $5.5582 \mathrm{e}-05$ & $(1.9330 \mathrm{e}-01)$ \\
\hline D(PRODIND)-2 & $\begin{array}{c}-5.8173 \mathrm{e}-02 * * * \\
(-6.9728 \mathrm{e}-06)\end{array}$ & $\begin{array}{r}-0.9 \\
(-0\end{array}$ & $\begin{array}{l}87 * * * \\
008)\end{array}$ \\
\hline
\end{tabular}

\begin{tabular}{lcc}
\hline Higher Regime & $\mathrm{D}($ EUAFUT $)$ & $\mathrm{D}($ PRODIND $)$ \\
\hline Constant & $0.09878^{* * *}$ & $0.09020 * * *$ \\
& $(0.0003)$ & $(0.0002)$ \\
D(EUAFUT)-1 & $5.0073 \mathrm{e}-03 * * *$ & -0.0938 \\
& $(2.7073 \mathrm{e}-06)$ & $(-0.1770)$ \\
D(PRODIND)-1 & $5.8413 \mathrm{e}-02 * * *$ & $-0.0270 * * *$ \\
& $(3.225 \mathrm{e}-06)$ & $(-0.0001)$ \\
D(EUAFUT)-2 & $-0.0824 * * *$ & -0.4474 \\
& $(0.0009)$ & $(0.7693)$ \\
D(PRODIND)-2 & $0.0187 * * *$ & $0.3778 * * *$ \\
& $(0.0007)$ & $(0.0003)$ \\
\hline
\end{tabular}

Table 4: TVAR Model for EUAs and EU Industrial Production

Note : EUAFUT stands for the ECX EUA Futures price, and PRODIND for the EU Industrial Production Index. The operator $\mathrm{D}($.) refers to the log-return transformation of the time series. $* * *$ indicates statistical significance at the $1 \%$ level, $* *$ at the $5 \%$ level, and * at the $10 \%$ level. The values between parentheses denote the standard errors of the estimated coefficients. 
The results from the LR linearity tests are shown in the top panel of Table 4. During the first step, the null hypothesis of linearity is clearly rejected in favor of the presence of one or two thresholds in the data. During the second step, we conclude that the TVAR model with two thresholds is preferable. Table 4 also shows that the threshold value is equal to 0.0072 at delay $d=1$, and 0.0302 at delay $d=2$.

To put these values into perspective, Figure 3 plots the threshold variable and the threshold values for the TVAR model estimated with $\mathrm{CO}_{2}$ and macroeconomic variables. The threshold variable used is pictured in the top panel. The bottom panels represent, respectively, the ordered threshold variable detected with a trimming parameter of 10\% (see Lo and Zivot (2001)) and the threshold value (as a function of the SSR) results of the grid search procedure.

The TVAR estimates are reproduced in the bottom panels of Table 4. By minimizing the AIC as the usual criterion, the number of lags in the TVAR was set at two (for more details, see Balke (2000)). In what follows, we comment on the lower and higher regimes estimates. According to the "macroeconomic approach" defined in Section 3.2, the results confirm that significant influences exist between $\mathrm{CO}_{2}$ futures prices and macroeconomic activity (Alberola et al. (2008, 2009), Bredin and Muckley (2011), Mansanet-Bataller et al. (2011), Chevallier (2011b,c,d)). What is new is that these relationships are studied in a nonlinear framework, as advised by Chevallier (2011e).

The results are qualitatively similar between the lower- and higher-regimes. Namely, in the lowerregime, we uncover the strong influence on the carbon price coming from the industrial production index, in addition to the autoregressive component. Regarding the sign, we observe logically that during the lower-regime, the (downward sloping) aggregated industrial production index affects negatively the carbon price. On the contrary, there is no "bounce back effect" from the carbon price to the EU industrial production, for which only lagged values of the index are found to be statistically significant (at the $1 \%$ level).

In the higher-regime, we are able to detect not only the statistical influence of the AR(1) and AR(2) processes on the carbon price, but also of the macroeconomic activity proxy lagged one and two periods (all at the 1\% level). When the industrial production is on the uptake, we detect positive influences on the carbon price, according to the underlying economic mechanisms at stake (as described in Section 3.1). Therefore, it seems that the carbon-macroeconomy relationship varies nonlinearly with respect to the threshold identified.

In the lower regime, the carbon price could be related mainly to institutional events (Conrad et al. (2012)), while the higher-regime findings are conform to previous literature (see, among others, Mansanet-Bataller et al. (2007), Hintermann (2010) and Pinho and Madaleno (2011)). Alberola et al. (2008) noted previously that the relationship between the carbon price and its main drivers changes before and after the occurrence of structural breaks. We are able to confirm their intuition based on the TVAR nonlinear model, which specifies the presence of several regimes in the data.

Hence, our interpretation in terms of macroeconomic drivers for the carbon market hold both during the lower- and higher regimes, which has been documented recently in the literature (Bredin and Muckley (2011), Chevallier (2011b,c,d), Mansanet-Bataller et al. (2011)). Taken together, these results yield to new insights into the relationship between the $\mathrm{CO}_{2}$ price and the macroeconomy compared to the linear regression framework (Alberola et al. $(2008,2009)$ ). 
Figure 3: TVAR Estimation Results for EUAs and EU Industrial Production

Threshold variable used



Ordered threshold variable

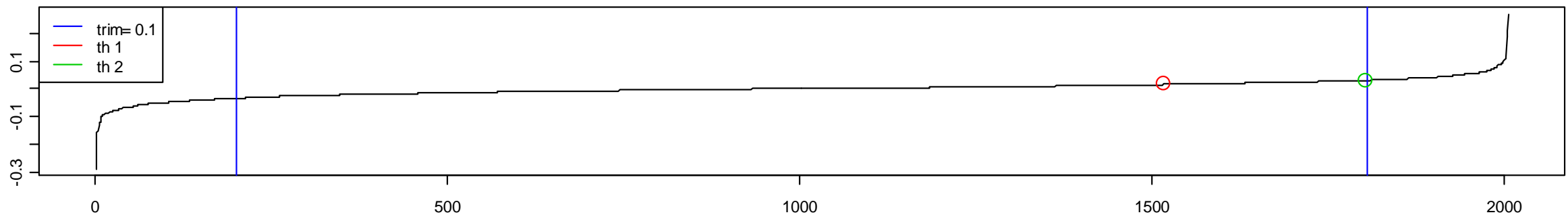

Results of the grid search






\subsection{Diagnostic test}

Here, we discuss some formal statistical approaches to model diagnostics via residual analysis (Cryer and Chan (2008)). Namely, we consider the generalization of the portmanteau test based on some overall measure of the magnitude of the residual autocorrelations. The dependence of the residuals necessitates the employment of a quadratic form of the residual autocorrelations:

$$
B_{m}=T_{e f f} \sum_{i=1}^{m} \sum_{j=1}^{m} q_{i, j} \hat{\rho}_{i} \hat{\rho}_{j}
$$

where $T_{\text {eff }}=T-\max \left(p_{1}, p_{2}, d\right)$ is the effective sample size, $\left(p_{1}, p_{2}\right)$ are the lag orders, $d$ is the delay parameter, $\hat{\rho}_{i}$ is the $i$ th lag sample autocorrelation of the standardized residuals, and $q_{i, j}$ some model-dependent constants given in Cryer and Chan (2008). If the true model is a TVAR model, the $\hat{\rho}_{i}$ are likely close to zero and so is $B_{m}$, but $B_{m}$ tends to be large if the model specification is incorrect. The quadratic form is designed so that $B_{m}$ is approximately distributed as $\chi^{2}$ with $m$ degrees of freedom. In practice, the $p$-value of $B_{m}$ may be plotted against $m$ over a range of $m$ values to provide a more comprehensive assessment of the independence assumption on the standardized errors.

Model diagnostics are shown in Figure 4. The top panel represents the time series plot of the standardized residuals of the TVAR model for EUAs and macroeconomic variables. Except for some possible outliers, the plot shows no particular pattern (as the standardized residuals are scattered around zero). The middle panel is the Auto-Correlation Function (ACF) plot of the standardized residuals. The confidence band is based on the simple $1.96 / \sqrt{T}$ rule, and should be regarded as a rough guide on the significance of the residual ACF. No lags in the residual autocorrelation are found to be significant. The bottom panel reports the $p$-values of the more rigorous portmanteau test. The $p$-values are found to be very large for all $m$. As no $p$-value is found to be significant (i.e. we do not reject the null hypothesis of no autocorrelation in the residuals), we may infer that the TVAR model is well-specified. 
Figure 4: Residuals Autocorrelation for EUAs and EU Industrial Production
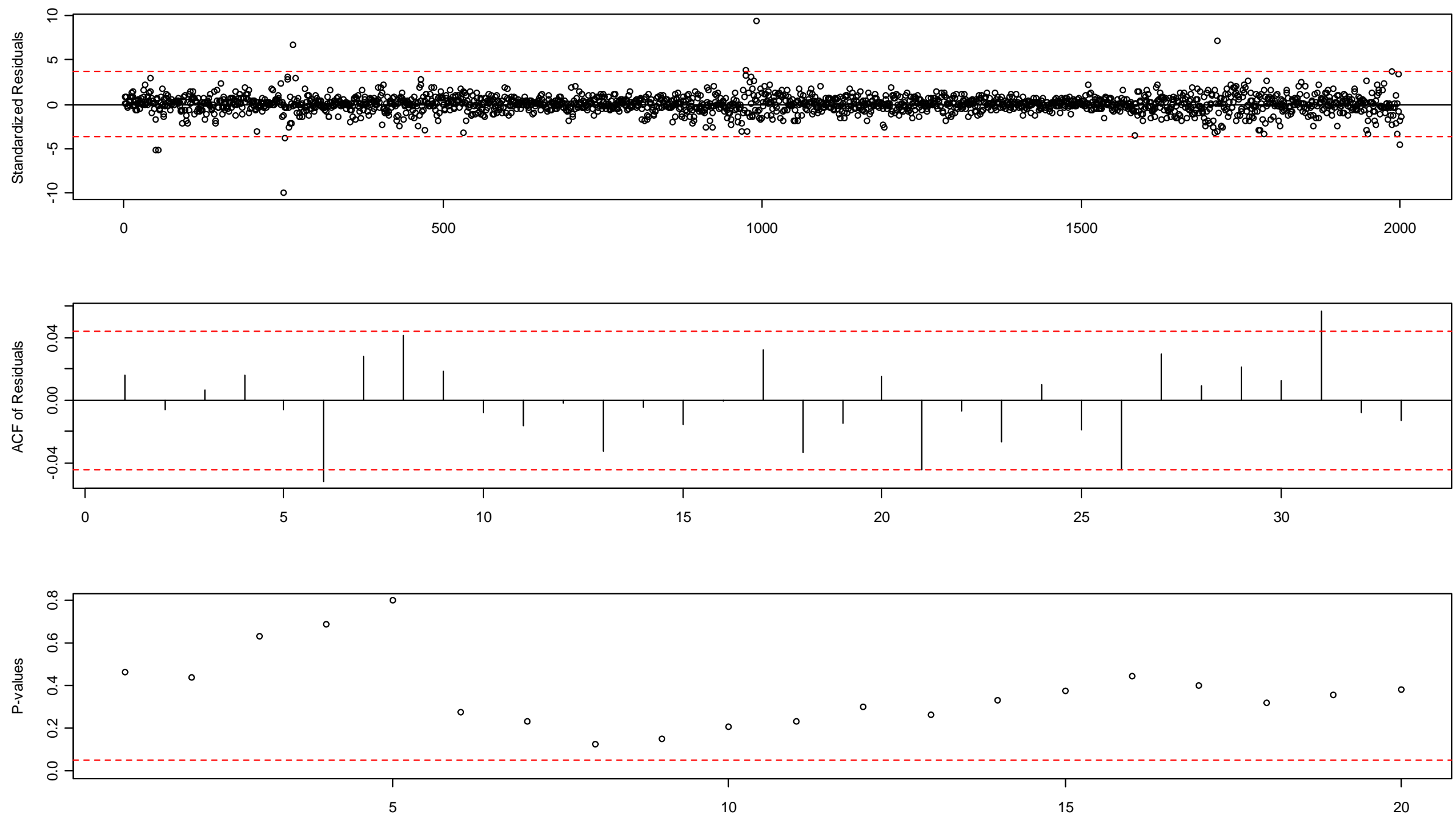


\section{Conclusion}

This chapter is dedicated to the analysis of the adjustment between the carbon futures price - taken from the European Climate Exchange - and macroeconomic activity - proxied by the Eurostat EU 27 Industrial Production index. Despite being amongst the chief carbon price drivers (if not the central), economic activity is indeed often forgotten in empirical studies, which omit it in favor of equity variables (e.g. the Eurostoxx 50 index).

Two main approaches seem to co-exist in the literature so far: (i) the "financial markets" approach, and (ii) the "macroeconomic activity" approach. Some scholars have attempted to build mixed equity-macroeconomy strategies. Our central contribution is to recall that, besides energy and institutional variables, there exists a channel of influence which goes from the state of current production levels (e.g. whether industrial production capabilities are "tense" or "idle") to the carbon price.

The underlying economic logic unfolds as follows: when economic activity (and industrial production taken here as a by-product) increases, then $\mathrm{CO}_{2}$ emissions mechanically increase (in absence of short-term energy efficiency gains). This translates ultimately in carbon price increases, ceteris paribus. We have been able to verify this relationship in the Threshold VAR framework, with a sample spanning April 2005-January 2013. Extensions of this line of work lie in the field of nonlinear time series econometrics ${ }^{12}$.

\footnotetext{
${ }^{12}$ See Chevallier (2011b) for a brief introduction.
} 


\section{References}

Aatola, P., Ollikainen, M., Toppinen, A. 2013. Price determination in the EU ETS market: Theory and econometric analysis with market fundamentals. Energy Economics 36:380-395

Alberola, E., Chevallier, J., and Cheze, B. 2008. The EU Emissions Trading Scheme: the Eff ects of Industrial Production and $\mathrm{CO}_{2}$ Emissions on European Carbon Prices. International Economics 11: 93-126

Alberola, E., Chevallier, J., and Cheze, B. 2009. Emissions Compliances and Carbon Prices under the EU ETS: A Country Specific Analysis of Industrial Sectors. Journal of Policy Modeling 31(3): 446-462

Balke, N.S. 2000. Credit and Economic Activity: Credit Regimes and Nonlinear Propagation of Shocks. Review of Economics and Statistics 82(2): 344-349

Bredin, D. and Muckley, C. 2011. An emerging equilibrium in the EU emissions trading scheme. Energy Economics 33: 353-363

Bunn, D.W., and Fezzi, C. 2009. Structural interactions of European carbon trading and energy prices. Journal of Energy Markets 2(4): 53-69

Chevallier, J. 2009. Carbon futures and macroeconomic risk factors: A view from the EU ETS. Energy Economics 31(4): 614-625

Chevallier, J. 2011a. Macroeconomics, finance, commodities: Interactions with carbon markets in a data-rich model. Economic Modelling 28(1-2): 557-567

Chevallier, J. 2011b. Econometric Analysis of Carbon Markets: The European Union Emissions Trading Scheme and the Clean Development Mechanism. Springer

Chevallier, J. 2011c. Evaluating the carbon-macroeconomy relationship: Evidence from threshold vector error-correction and Markov-switching VAR model. Economic Modelling 28(6):2634-2656

Chevallier, J. 2011d. A Model of Carbon Price Interactions with Macroeconomic and Energy Dynamics. Energy Economics 33(6): 1295-1312

Chevallier, J. 2011e. The impact of nonlinearities for carbon markets analyses. International Economics 126-127:131-150

Christiansen, A., Arvanitakis, A., Tangen, K., and Hasselknippe, H. 2005. Price determinants in the EU emissions trading scheme. Climate Policy 5 : 15-30

Creti, A., Jouvet, P.A. and Mignon, V. 2012. Carbon price drivers : Phase I versus Phase II equilibrium ? Energy Economics 34: 327-334

Cryer, J.D. and Chan, K.S. 2008. Time series analysis with applications in $R, 2^{\text {nd }}$ Edn. Springer Texts in Statistics, Springer, New York, USA 
Ellerman, A.D., Convery, F.J., De Perthuis, C., 2010. Pricing carbon: the European Union emissions trading scheme. Cambridge University Press, Cambridge.

Franses, P.H. and van Dijk, D. 2003. Non-Linear Time Series Models in Empirical Finance, Second Edition, Cambridge University Press, Cambridge, UK

Hansen, B. 1996. Inference When a Nuisance Parameter Is Not Identified Under the Null Hypothesis. Econometrica 64: 413-430

Hansen, B. 1999. Testing for Linearity. Journal of Economic Surveys 13(5): 551-576

HFW. 2012. EU Emissions Trading Scheme Becomes Reality. Client Brief, Holman Fenwick Willan, UK. Last accessed October 2012.

http://www.hfw.com/_data/assets/pdf_file/0019/17713/Client-Brief-EU-Emissions-Trading-

Scheme-Becomes-Reality-for-Airlines-A4-6pp-January-2012.pdf

Hinterman, B. 2010. Allowance price drivers in the first phase of the EU ETS. Journal of Environmental Economics and Management 59: 43-56

Kanen, J.L.M. 2006. Carbon Trading and Pricing, Environmental Finance Publications

Lo, M.C. and Zivot, E. 2001. Threshold Cointegration and Nonlinear Adjustment to the Law of One Price. Macroeconomic Dynamics 5(4): 533-576

Mansanet-Bataller, M., Chevallier, J., Herve-Mignucci, M. and Alberola, E. 2011. EUA and sCER Phase II Price Drivers: Unveiling the reasons for the existence of the EUA-sCER spread. Energy Policy 39(3): 1056-1069

Mansanet-Bataller, M., Pardo, A., and Valor, E. 2007. $\mathrm{CO}_{2}$ prices, energy and weather. Energy Journal 28(3): 73-92

Pinho, C., Madaleno, M. 2011. $\mathrm{CO}_{2}$ emission allowances and other fuel markets interactions, Environmental Economics and Policy Studies 13, 259-281.

Springer, U. 2003. The market for tradable GHG permits under the Kyoto Protocol: A survey of model studies. Energy Economics 25 (5): 527-51

Tendances Carbone. 2013. The EU ETS, a good example of a "zombie" public policy. Tendances Carbone 80, CDC Climat, Paris, France. Last accessed May 2013:

http://www.cdcclimat.com/IMG//pdf/tendances_carbone_cdc_climat_research_no80_veng.pdf

Teräsvirta, T., Tjostheim, D., Granger, C.W.J. 2011. Modelling nonlinear economic time series: Advanced texts in econometrics, Oxford University Press, Oxford, UK. UK

Tong, H. 1990. Non-linear time series: a dynamical system approach, Clarendon Press, Oxford, 